Creative commons User License: CC BY-NC-ND

Abstracted by: EBSCOhost, Electronic Journals Service (EJS),

Google Scholar, Directory of Open Access Journals (DOAJ),

Journal Seek, Scientific Commons,

Food and Agricultural Organization (FAO), and $C A B I$
Journal of Agricultural Extension

Vol. 20 (1) June, 2016

ISSN(e): 24086851; ISSN(Print); $1119944 X$

http://journal.aesonnigeria.org

http://www.ajol.info/index.php/jae

Email: editorinchief@aesonnigeria.org

\title{
Adoption of Root and Tuber Technologies Disseminated by the National Root Crops Research Institute in Anambra State Http://dx.doi.org/10.4314/jae.v20i1.4
}

Ironkwe, Adanma Glory

Minor Root Crops Research Programme

National Root Crops Research Institute Umudike

Abia State Nigeria

Email: adanmaironkwe@gmail.com

Phone: 08038449503

\section{Ezebuiro, Nathaniel Chika}

Extension Services Programme

National Root Crops Research Institute Umudike

Abia State Nigeria

Email: ezebuirochikason@yahoo.com

Phone: 08063885049

\section{Ewuziem, Justin Enyinnaya}

Ginger Research Programme

National Root Crops Research Institute Umudike

Abia State Nigeria

Email: juziem2000@yahoo.com

Phone: 08064833657

\section{Abstract}

The study examined the diffusion and adoption of National Root Crops Research Institute disseminated technologies and factors influencing them in Anambra State. Two agricultural zones of the State, Awka and Anambra were randomly selected for the study, out of the existing four Agricultural zones in the State. Structured interview schedule was used to elicit information from 171 respondents. The result revealed that a greater number of the respondents were within the age range of $41-$ 60 years, and about $94.15 \%$ were educated at different levels. Five (5) out of the eighteen (18) technologies evaluated were adopted, while factors such as scarcity of inputs, high cost of fertilizer and labour, scarcity of planting materials, among others militated against the adoption of the technologies. Among the four functional form of regression models tried out, the linear model had the best fit and used in the analysis. The regression output showed that age, sex, farming experience and membership of cooperative societies were significant at $1 \%$ level of probability. Further efforts on promotion and popularization of root and tuber crops based technologies should be embarked upon to enhance more adoption of the Institute's technologies and to increase the productivity of the farmers in the state. 
Key words: Adoption and Diffusion, Root and Tuber Crops Technologies, National Root Crops Research Institute

\section{Introduction}

Adoption and diffusion theory according to Rogers and Shoemaker (1971) has to do with innovation decision process. It stated that a potential adopter passes through a mental process from first knowledge of the innovation to a decision time to adopt or reject, and to confirmation of his decision. Based on the theory, many social scientists have formulated different models consisting of different number of stages for example, the Subcommittee's (1961) model called "the

Adoption process" postulated by the North Central Rural Sociology Subcommittee for the study of diffusion of farm practices. This consists of five stages namely, Awareness, Interest, Evaluation, Trail and Adoption (AIETA) (Ekong, 2010). Adoption consists of all activities pertaining to problem perception, information gathering, attitude formation and evaluation, and resources obtained leading to the decision to adopt. Loevinsohn et al (2012) defines adoption as the integration of a new technology into existing practice and is usually proceeded by a period of trying' and some degree of adaptation. It is a continuous process that takes time to mature and diffuse into a wider range (Ironkwe, 2005). According to Alade (2011), adoption of any innovation or idea is a mental process which an individual pass through before deciding to continue full use of any innovation or not. Adoption of improved agricultural technologies has been associated with: higher earnings and lower poverty; improved nutritional status; lower staple food prices; increased employment opportunities as well as earnings for landless labourers (Mwangi, and Kariuki, (2015).

The processes of adoption (AIETA) are being influenced by different factors such as social system, personal characteristics of the farmer, technical characteristics of the innovation and so forth. Over the years many studies have been conducted on innovation and uptake of new technologies in developing countries. In addition, the process of adoption and the impact of adopting new technology on smallholder farmers have been studied. However new agricultural technologies are often adopted slowly and several aspects of adoption remain poorly understood despite being seen as an important route out of poverty in most of the developing countries (Mwangi, and Kariuki, (2015); Simtowe, 2011).

National Root Crops Research Institute (NRCRI), Umudike has developed and transferred different technologies on root and tuber crops to farmers in Nigeria to increase their productivity and income. What happened to those technologies generated from the Institute and transferred to the farmers for 
adoption and the reactions of the farmers to such technologies are important issue to consider.

Increasing agricultural productivity is critical to meet expected rising demand and, as such, it is instructive to examine recent performance in cases of modern agricultural technologies (Challa, 2013). This study examined the adoption and diffusion of some NRCRI, disseminated technologies and factors influencing their adoption in Anambra State.

The specific objectives were to:

- describe the socio-economic characteristics of the respondents.

- ascertain extent of farmers' awareness and adoption of selected technologies disseminated over 5 years by the Institute.

- determine the factors influencing adoption of the technologies and

- identify constraints militating against adoption of root and tuber crops technologies.

\section{Methodology}

\section{Study Area}

The study was conducted in Anambra State, Nigeria. The State is one of the 36 States in the country. It is bordered by the following States: Imo in the South, Enugu in the East, Delta in the west and Kogi States in the North. The State lies between Latitude $6^{\circ} .20^{\prime} \mathrm{N}$ and Longitude $7^{\circ} .00^{\prime} \mathrm{E}$, and covers an area of about $4,844 \mathrm{~km}^{2}$. According to 2006 population census, the state has a human population of about $4,055,048$ with a density of $840 / \mathrm{km}^{2}$.It has derived savannah vegetation, humid climate with an average annual temperature of about $29^{\circ} \mathrm{C}$ and rainfall between $1,500 \mathrm{~mm}-2,000 \mathrm{~mm}$ (NPC, 2006, www.anambrastate.gov.ng).

Most of the farmers in the State are found in rural areas and cultivate mostly root and tuber crops, they depend greatly on agriculture for their livelihood.

\section{Sampling technique}

Multi-stage random sampling technique was adopted in the study. At the first stage, Awka and Anambra zones were randomly selected out of the four agricultural zones of the State. At the second stage, two blocks from each of the selected zones were selected. Furthermore, two circles were randomly selected from the selected blocks. Finally, 43 farmers were randomly selected in each block from the lists of farmers collected from the extension agents in charge of the circles in the selected blocks, this list constituted the sampling 
frame for the study. Primary data on the socioeconomic characteristics of the farmers, frequencies of farmers on each stage of the adoption process, factors influencing adoption and constraints to adoption was collected with the aid of an interview schedule administered to the farmers. A total of 172 farmers were interviewed out of which 171 were completely filled and returned; thus constituting the sample size, hence the analysis was based on this number (171). Adoption was measured by the frequencies of the farmers on each stage of adoption and calculating the mean scores. A mean score of 3.0 and above for a technology, indicates adoption.

\section{Data Analysis}

Descriptive and inferential statistical tools were used to analyse the data. This involved the use of frequency table, percentages, means etc. Also, the multiple regression analysis was employed to determine the influence of certain socio-economic variables on adoption of the technologies. Four functional forms (linear, exponential, semi-log and double-log) of multiple regression models were tried out in the analysis. The linear regression model was specified implicitly as:

$Y=f\left(X_{1}, X_{2}, X_{3}, X_{4}\right.$

$Y=$ the adoption index (number of technologies adopted by a farmer)

$\mathrm{X}_{1}=$ Age of the farmers in years

$\mathrm{X}_{2}=$ Sex, (dummy variable Male $=1$, Female $=0$ )

$X_{3}=$ Marital status, (dummy variable Married $=1$, Single $=0$ )

$\mathrm{X}_{4}=$ Farming experience in years

$X_{5}=$ Household size - number of persons in the household

$X_{6}=$ Level of Education (number of years spent in school)

$\mathrm{X}_{7}=$ Type of farmer (dummy variable, full-time $=1$, part-time $=0$ )

$\mathrm{X}_{8}=$ Farm size in hectares

$\mathrm{X}_{9}=$ Extension contact (dummy variable, contact with extension agent $=1$, non $=0$ )

$X_{10}=$ Membership of farmers' cooperative (dummy variable, members $=1$, non-member $=0$ )

$X_{11}=$ Income in Naira

$\mathrm{e}=$ Error term

\section{Result and Discussions}

The result revealed that a majority of the respondents were between 41 to 60 years old $(57.89 \%)$ as shown in table 1 . This is an economic and productive stage which may enhance adoption of technologies. Age is assumed to be a determinant of adoption of new technology. Older farmers are assumed to have gained knowledge and experience over time and are better able to evaluate technology information than younger farmers (Mignouna et al, 2011; 
Creative commons User License: CC BY-NC-ND

Abstracted by: EBSCOhost, Electronic Journals Service (EJS), Google Scholar, Directory of Open Access Journals (DOAJ),

Journal Seek, Scientific Commons,

Food and Agricultural Organization (FAO), and CABI
Journal of Agricultural Extension

Vol. 20 (1) June, 2016

ISSN(e): 24086851; ISSN(Print); 1119944X

http://journal.aesonnigeria.org

http://www.ajol.info/index.php/jae

Email: editorinchief@aesonnigeria.org

Kariyasa and Dewi 2011). Furthermore, greater proportions of the farmers were married (95.9\%) and had between 11 to 30 years of farming experience. For many years of farming experience indicated by most of the respondents, it could be assumed that they possessed sufficient indigenous skill and knowledge required in root and tuber crops production. This basically would encourage adoption of these technologies. More than $80 \%$ of the respondents had 4 to 9 persons in their households. This large household size invariably favours the availability of labour and encourages adoption of technologies. The results also showed that majority of the respondents had secondary school education (40.35\%). This implies that the educational status of the respondents is relevant to enhance adoption of the technologies since acquisition of formal education is supposed to enhance one's ability to understand and evaluate new production techniques (Onyenweaku and Nwaru, 2005, and Nwaru, 2007). Education of the farmer has been assumed to have a positive influence on farmers' decision to adopt new technology. Education level of a farmer increases his ability to obtain; process and use information relevant to adoption of a new technology (Mignouna et al., 2011; Lavison 2013; Namara et al., 2013). A majority indicated having access to loan, land and market which could also favour adoption of the technologies in the study area. 
Creative commons User License: CC BY-NC-ND

Abstracted by: EBSCOhost, Electronic Journals Service (EJS), Google Scholar, Directory of Open Access Journals (DOAJ), Journal Seek, Scientific Commons,

Food and Agricultural Organization (FAO), and CABI
Journal of Agricultural Extension

Vol. 20 (1) June, 2016

ISSN(e): 24086851; ISSN(Print); $1119944 X$

http://journal.aesonnigeria.org

http://www.ajol.info/index.php/jae

Email: editorinchief@aesonnigeria.org

\section{Table 1: Socio-economic characteristics of the respondents}

\begin{tabular}{lc}
\hline Age (years) & Percentage \\
$<20$ years & $1.17(2)$ \\
$21-30$ & $4.09(7)$ \\
$31-40$ & $8.77(15)$ \\
& \\
$41-50$ & $28.65(49)$ \\
$51-60$ & $29.24(50)$ \\
Above 60 & $28.07(48)$ \\
Marital Status & \\
Married & $95.91(164)$ \\
Single & $4.09(7)$ \\
Farming Experience & \\
$\quad 1-10$ years & $29.24(50)$ \\
$11-20$ years & $35.67(61)$ \\
$21-30$ years & $24.56(42)$ \\
Above 30 years & $10.53(16)$ \\
Household Size & \\
$\quad 1-3$ & $12.28(21)$ \\
$\quad 4-6$ & $49.12(84)$ \\
$\quad 7-9$ & $31.58(54)$ \\
Above 9 & $7.02(12)$ \\
Educational status & \\
No School & \\
Primary & $5.85(10)$ \\
Secondary & $35.67(61)$ \\
Tertiary & $40.35(67)$ \\
Access to loan & $18.13(31)$ \\
Yes & \\
No & \\
Access to land & \\
Yes & $56.14(96)$ \\
Access to market & $43.86(75)$ \\
Yes & \\
No & \\
* The figures in parenthesis & are the frequencies \\
&
\end{tabular}


Creative commons User License: CC BY-NC-ND

Abstracted by: EBSCOhost, Electronic Journals Service (EJS), Google Scholar, Directory of Open Access Journals (DOAJ), Journal Seek, Scientific Commons,

Food and Agricultural Organization (FAO), and CABI
Journal of Agricultural Extension

Vol. 20 (1) June, 2016

ISSN(e): 24086851; ISSN(Print); 1119944X

http://journal.aesonnigeria.org

http://www.ajol.info/index.php/jae

Email: editorinchief@aesonnigeria.org

The level of adoption of the technologies is shown in table 2 below. The results indicated that white yam (3.98), Edeofe (3.75), Sweet potato flour (3.04), Sweet potato chips (3.23) and land clearing (3.43) were at full adoption stages while the other technologies were yet to be adopted in the study area.

Table 2: Levels of adoption of some selected root and tuber crops technologies in Anambra state

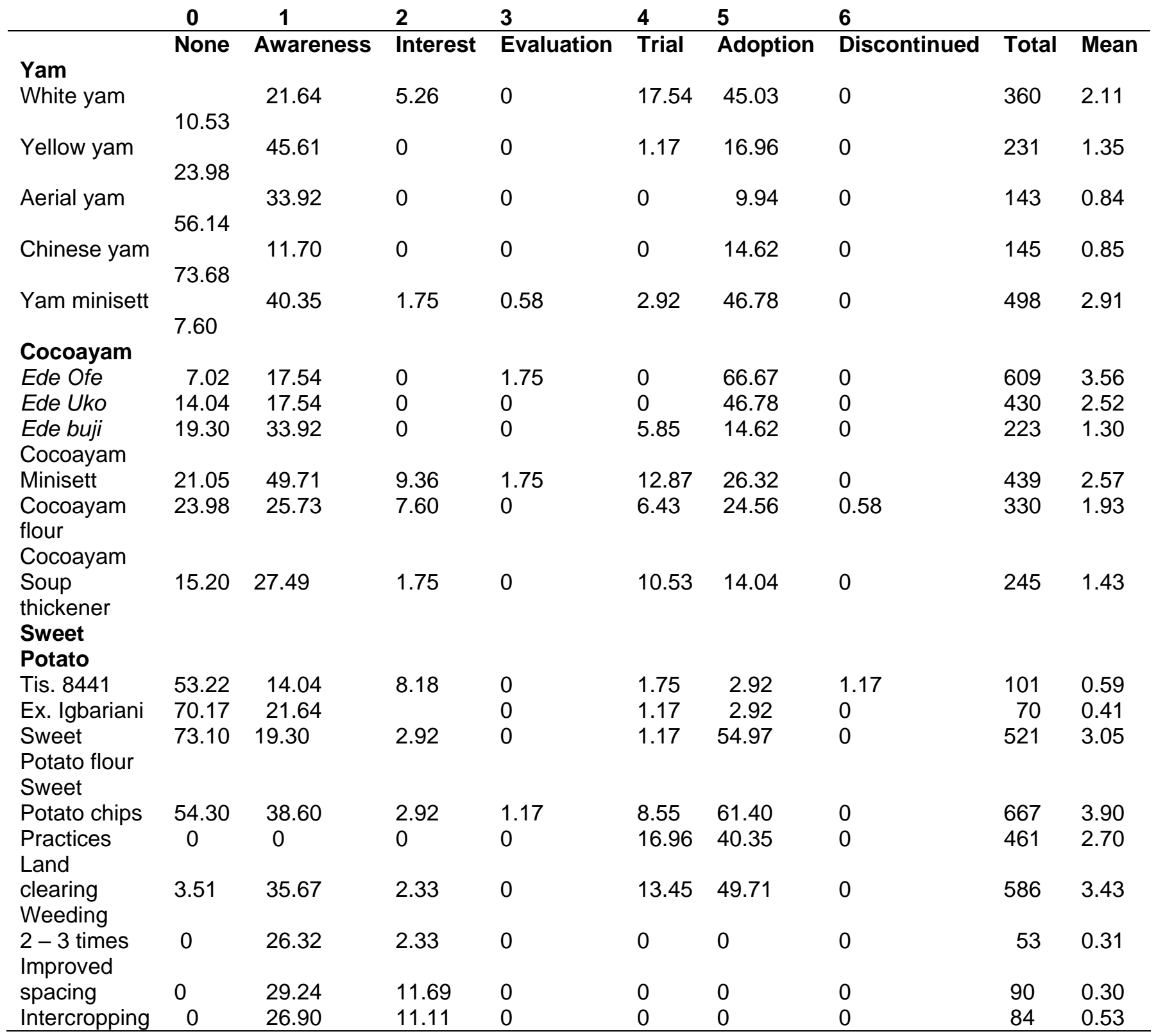


Creative commons User License: CC BY-NC-ND

Abstracted by: EBSCOhost, Electronic Journals Service (EJS),

Google Scholar, Directory of Open Access Journals (DOAJ),

Journal Seek, Scientific Commons,

Food and Agricultural Organization (FAO), and CABI
Journal of Agricultural Extension

Vol. 20 (1) June, 2016

ISSN(e): 24086851; ISSN(Print); 1119944X

http://journal.aesonnigeria.org

http://www.ajol.info/index.php/jae

Email: editorinchief@aesonnigeria.org

The inability of the farmers to adopt most of the technologies could be attributed to the several factors. In some cases, the characteristics of the technology play a significant role. Mignouna et al. (2011) stated that, the characteristic of the technology plays a critical role in adoption decision process. They argued that farmers who perceive the technology being consistent with their needs and compatible to their environment are likely to adopt since they find it as a positive investment. Farmers' perception about the performance of the technologies significantly influences their decision to adopt them. For ease of adoption, Karugia et al., (2004) suggested that for any new technology to be introduced to farmers, they should be involved in its evaluation to find its suitability to their circumstances.

The study identified some constraint militating against adoption of these technologies. Among these factors, scarcity of input, high cost of fertilizer, lack of access to credit, problems of land and high cost of labour are prominent.

\section{Table 3: Distribution of respondents according to the constraints militating against adoption of agricultural technologies}

\begin{tabular}{lll}
\hline S/N. & Constraints & Percentage \\
1 & Scarcity of input & 87.72 \\
2 & High cost of fertilizer & 77.19 \\
3 & Lack of access to credit & 65.50 \\
4 & Problem of land & 52.63 \\
5 & High cost of labour & 49.12 \\
6 & Scarcity of planting materials & 47.95 \\
7 & Poverty & 38.60 \\
8 & Crude implement & 38.01 \\
9 & Poor extension contact & 33.33 \\
10 & Poor weather condition & 12.87 \\
\end{tabular}

Most technologies come with a production packages that have specific requirements to achieve the target output. Some of the inputs required to achieve this targets are scarce, forcing the farmer to loose interest in the technology. This is in line with the findings of Ironkwe (2011) that scarcity and or high cost of production inputs affects the adoption of a new technology by farmers negatively.

This result gives credence to previous studies of Makokha et al (2001) and Ouma et al. (2002) that reported high cost of labour, hired labour and other inputs, unavailability of demanded packages and untimely delivery as the main constraints to fertilizer adoption in Kenya. Lack of access to credit has been implicated in previous studies to hinder adoption. Access to credit has been reported to stimulate technology adoption (Mohamed \& Temu, 2008). It is believed that access to credit promotes the adoption of 
Creative commons User License: CC BY-NC-ND

Abstracted by: EBSCOhost, Electronic Journals Service (EJS),

Google Scholar, Directory of Open Access Journals (DOAJ),

Journal Seek, Scientific Commons,

Food and Agricultural Organization (FAO), and CABI
Journal of Agricultural Extension

Vol. 20 (1) June, 2016

ISSN(e): 24086851; ISSN(Print); $1119944 X$

http://journal.aesonnigeria.org

http://www.ajol.info/index.php/jae

Email: editorinchief@aesonnigeria.org

risky technologies through relaxation of the liquidity constraint as well as through the boosting of household's-risk bearing ability (Simtowe \& Zeller, 2006). When credit is lacking, adoption becomes difficult.

The result of the socioeconomic determinants of adoption in the study area is shown in table 4. Out of the four functional forms of the regression models tested, the linear form, having the highest number of significant variables and an $R^{2}$ value of 0.983 , had the best fit and was selected as the lead equation and used in the analysis. The $R^{2}$ value of 0.983 indicates that the independent variables used in the regression model were able to explain $98 \%$ of the variability in the dependent variable (y). Although the exponential function had a higher $R^{2}$ value of 0.994 , it was not selected as the lead equation because it had fewer significant variables. Other functional forms had lower $\mathrm{R}^{2}$ values than the linear form used in the analysis.

The regression output showed that age, sex, farming experience and membership of cooperative societies were very strong determinants of adoption in the State as these variables were significant at $1 \%$ level of probability. Meanwhile, age and sex had negative relationships with adoption. This implies that as the respondents grow older, they tend to reject these technologies whereas the younger ones have a higher probability of accepting and using them. This result is in agreement with the findings of Ironkwe (2005) in the adoption of minisett technology in Abia State, Nigeria. Also sex negatively influenced adoption, implying that the technologies disseminated are gender sensitive technologies which should target a particular gender group based on the farming culture of people and the types of root and tuber crops involved. This result further confirms the report by Bonabana-Wabbi (2002) expressing mixed evidence regarding the different roles men and women play in technology adoption. Gender affects technology adoption since the head of the household is the primary decision maker and men have more access to and control over vital production resources than women due to socio-cultural values and norms (Mesfin, 2005; Omonona et al., 2005; Mignouna et al., 2011). 
Table 4: Effects of socio- economic characteristics of the respondents on adoption of the technologies

\begin{tabular}{|c|c|c|c|c|}
\hline Variables & Linear & Semi log & Double log & Exponential \\
\hline Adoption (Y) & $\begin{array}{c}115.273^{* \star \star} \\
(40.412)\end{array}$ & $\begin{array}{c}4.909 \\
(46.965)\end{array}$ & $\begin{array}{l}-6.005^{\star \star \star} \\
(-5.128)\end{array}$ & $\begin{array}{l}-18.336 \\
(-1.352)\end{array}$ \\
\hline Age & $\begin{array}{l}-1.352^{* * *} \\
(-12.083)\end{array}$ & $\begin{array}{l}-0.020 * * * \\
(-4.963)\end{array}$ & $\begin{array}{l}2.172^{\star \star \star} \\
(5.173)\end{array}$ & $\begin{array}{r}2.603 \\
(0.535)\end{array}$ \\
\hline Sex & $\begin{array}{r}1.060^{\star * *} \\
(2.612)\end{array}$ & $\begin{array}{r}0.002 \\
(0.125)\end{array}$ & $\begin{array}{l}0.011 \\
(0.341)\end{array}$ & $\begin{array}{l}-1.054^{\star * *} \\
(-2.780)\end{array}$ \\
\hline Marital status & $\begin{array}{r}-1.034 \\
(-3.462)\end{array}$ & $\begin{array}{l}-0.042 \\
(-1.057)\end{array}$ & $\begin{array}{l}-0.004 \\
(-0.097)\end{array}$ & $\begin{array}{l}-0.394 \\
(-0.926)\end{array}$ \\
\hline Farming experience & $\begin{array}{r}-1.034^{* * *} \\
(-0.951)\end{array}$ & $\begin{array}{l}-0.006 \\
(-0.097)\end{array}$ & $\begin{array}{l}0.115 \\
(0.726)\end{array}$ & $\begin{array}{l}24.722^{* * *} \\
(13.520)\end{array}$ \\
\hline Household size & $\begin{array}{l}0.164^{*} \\
(1.853)\end{array}$ & $\begin{array}{l}-0.005 \\
(-1.425)\end{array}$ & $\begin{array}{l}-0.018 \\
(-0.337)\end{array}$ & $\begin{array}{l}-0.791 \\
(-1.276)\end{array}$ \\
\hline Education & $\begin{array}{l}0.644^{* * *} \\
(3.051)\end{array}$ & $\begin{array}{l}0.013 \\
(1.643)\end{array}$ & $\begin{array}{l}-0.049 \\
(-1.193)\end{array}$ & $\begin{array}{l}-0.477 \\
(-1.001)\end{array}$ \\
\hline Type of farmer & $\begin{array}{l}-0.174 \\
(-0.949)\end{array}$ & $\begin{array}{l}-0.005 \\
(1.643)\end{array}$ & $\begin{array}{l}0.033 \\
(0.660)\end{array}$ & $\begin{array}{l}-0.572 \\
(-1.000)\end{array}$ \\
\hline Farm siz,e & $\begin{array}{l}-0.278 \\
(-0.949)\end{array}$ & $\begin{array}{l}-0.276^{\star \star} \\
(-14.159)\end{array}$ & $\begin{array}{l}-0.240^{* *} \\
(-2.056)\end{array}$ & $\begin{array}{r}1.750 \\
(1.293)\end{array}$ \\
\hline Extension contact & $\begin{array}{l}-0.060 \\
(-0.041)\end{array}$ & $\begin{array}{l}0.123^{* *} \\
(2.291)\end{array}$ & $\begin{array}{l}-0.108^{* * *} \\
(-2.493)\end{array}$ & $\begin{array}{c}-0.260 \\
(-0.515)\end{array}$ \\
\hline $\begin{array}{l}\text { Membership of } \\
\text { cooperative society }\end{array}$ & $\begin{array}{l}2.290^{\star * *} \\
(2.893)\end{array}$ & $\begin{array}{l}-0.093^{\star * *} \\
(-3.987)\end{array}$ & $\begin{array}{l}-0.022 \\
(-0.571)\end{array}$ & $\begin{array}{l}0.679 \\
(1.550)\end{array}$ \\
\hline Income & $\begin{array}{l}4.713 \mathrm{E}-8 \\
(0.318)\end{array}$ & $\begin{array}{l}-2.169 \mathrm{E}-8^{\star * *} \\
(-3.987)\end{array}$ & $\begin{array}{l}0.072 \\
(1.452)\end{array}$ & $\begin{array}{l}-1.037^{\star} \\
(-1.813)\end{array}$ \\
\hline $\mathrm{R} 2$ & 0.983 & 0.980 & 0.975 & 0.994 \\
\hline $\mathrm{R} 2$ - adjusted & 0.982 & 0.978 & 0.950 & 0.988 \\
\hline F-statistics & $843.942^{* * *}$ & $684.101^{* * *}$ & $117.306^{\star * *}$ & 523.331 \\
\hline
\end{tabular}

Education and membership of cooperative society positively and significantly influenced adoption at $1 \%$ level of probability. This means that they have a direct relationship with adoption. The more educated the farmer is the higher the probability of adoption. Education level of a farmer increases his ability to obtain; process and 
use information relevant to adoption of a new technology (Mignouna et al., 2011; Lavison 2013; Namara et al., 2013).

Membership of cooperative societies is positively significant to adoption which implies that the members of cooperatives societies were adopting the technologies more than the non-members. In recent times cooperative are veritable means of information gathering and sharing among members especially in agriculture. Most government programmes nowadays target cooperative societies as a vehicle to drive home innovations to the target group because it has been proved to be more efficient. Information dissemination and demonstration of proven technologies are now done through cooperatives. This is the most likely scenario that has played out in the study area. Members of cooperative societies adopt technologies faster because they know about it earlier before others. This result is in consonance with Nwaru, (2005). That farming experience is negative but significantly influenced adoption at $1 \%$ level of probability indicates that the more experienced farmers were not adopting the technologies as much as the less experienced ones. This result differs from that of Ironkwe et al (2011) whose result showed positive relationship between membership of cooperative societies and adoption of yam minisett technology in Southeastern Nigeria. Household size was positive and significant at $10 \%$ level of probability implying that the farmers with larger household sizes were likely to adopt the technologies.

\section{Conclusion and Recommendations}

Age, farming experience, educational status, membership of farmers' cooperatives and household size were the socio-economic factors influencing adoption of the technologies in the state. Lack of input, high cost of fertilizer, lack of fund, high cost of labour among others were the problems militating against the adoption of the technologies.

Promotion and popularization efforts should be embarked upon toward creating more awareness of the technologies among farmers in the State by the research institutes and the Agricultural Development Programmes. There is also need to provide credit facilities in form of soft loans to the farmer cooperatives by funding agencies to enable them hire labour, rent farm land and planting materials. Both the Federal and State government should ensure adequate provision of fertilizer to the farmers at subsidized rate and at the right time. Meanwhile, the farmers themselves should form cooperative societies through which they could have access to fertilizer, credits, agricultural information and production resources to enable them adopt the technologies to enhance their productivity and income. 


\section{References}

Alade, O.A. (2011). Assessing the adoption of family planning method among rural Women in Oyo State. Nigerian Journal of Rural Sociology Vol. 12 No. 2, December, 2011. pp. $49-57$.

Bonabana-Wabbi J. (2002). Assessing Factors Affecting Adoption of Agricultural Technologies: The Case of Integrated Pest Management (IPM) in Kumi District, Msc. Thesis Eastern Uganda

Challa, Merga (2013).Determining Factors and Impacts of Modern Agricultural Technology Adoption in West Wollega, Munich, GRIN Publishing GmbH, http://www.grin.com/en/e book/280336/determiningfactors-and-impacts-ofmodern-agricultural-technology-adoption.

Ekong, E. Ekong (2010). Rural Sociology. An Introduction and Analysis of Rural Nigeria. Social Change in Rural Nigeria pp. 292 - 294.

Ironkwe, A.G. (2005). Adoption of yam minisett technology by women farmers in Abia State, Nigeria. Unpublished MSc thesis in Department of Rural Sociology and Extension, MOUA, Umudike, Abia State, Nigeria.

Ironkwe, A.G., Unamma, R.P.A. and Nwosu, A.C. (2011). Gender involvement in technology utilization among small holder farmers in Southeastern Nigeria: The case of yam minisett technology. The Nigerian Agricultural Journal Vol. 42 (2011), 190 - 201.

Kariyasa, K., Dewi, A. (2011).Analysis of Factors Affecting Adoption of Integrated Crop Management Farmer Field School (Icm-Ffs) in Swampy Areas. International Journal of Food and Agricultural Economics 1(2): pp 29-38

Karugia, S., Baltenweck, I., Waithaka, M., Miano, M., Nyikal, R., Romney, D (2004). Perception of Technology and its Impact on Technology Uptake: The Case of Fodder Legume in Central Kenya Highlands. The Role of Social Scientists Proceedings of the Inaugural Symposium, 6 to 8 December 2004, Grand Regency Hotel, Nairobi, Kenya

Lavison, R. (2013). Factors Influencing the Adoption of Organic Fertilizers in Vegetable Production in Accra, Msc Thesis, Accra Ghana.

Loevinsohn M, Sumberg J, Diagne A (2012) under what circumstances and conditions does adoption of technology result in increased agricultural 
productivity? Protocol. London: EPPI Centre, Social Science Research Unit, Institute of Education, University of London

Makokha, S., Kimani, S., Mwangi, W., Verkuijl, H., Musembi, F. (2001). Determinants of Fertilizer and Manure Use for Maize Production in Kiambu District, Kenya. CIMMYT (International Maize and Wheat Improvement Center) Mexico

Mesfin A. (2005). "Analysis of factors Influencing Adoption of Triticale and its Impact. The Case Farta Wereda". Msc. Thesis (Unpublished) Presented to School of Graduate Studies of Alemaya University.

Mignouna, B., Manyong, M., Rusike, J., Mutabazi, S., \& Senkondo, M. (2011). Determinants of Adopting Imazapyr-Resistant Maize Technology and its Impact on Household Income in Western Kenya: AgBioforum, 14(3), 158-163. Hall, B. and Khan, B. (2002) Adoption of new technology. New Economy Handbook.

Mohamed, K. and Temu, A. (2008). Access to credit and its effect on the adoption of agricultural technologies: The case of Zanzibar. African Review of Money Finance and Banking: pp. 45-89

Mwangi, M and Kariuki, S. (2015) 'Factors Determining Adoption of New Agricultural Technology by Smallholder Farmers in Developing Countries'

Journal of Economics and Sustainable Development Vol.6, No.5,

Namara, E., Weligamage, P., Barker, R. (2013). Prospects for adopting system of rice intensification in Sri Lanka: A socioeconomic assessment. Research Report 75.Colombo, Sri Lanka: International Water Management Institute.

National Population Commission (NPC) (2006). www.anambrastate.gov.ng

Nwaru, J.C. (2005). Determinants of Farm and off-farm incomes and savings of food crop farmers in Imo State, Nigeria: Implications for poverty alleviation. The Nigerian Agricultural Journal Vol. 36 (2005) $26-42$.

Nwaru, J.C. (2007). Gender and relative technical efficiency in small holder arable crop production in Abia State Nigeria. International Journal of Agriculture and Rural Development (ISARD), 10 (2): 25 - 34. 
Creative commons User License: CC BY-NC-ND

Abstracted by: EBSCOhost, Electronic Journals Service (EJS),

Google Scholar, Directory of Open Access Journals (DOAJ),

Journal Seek, Scientific Commons,

Food and Agricultural Organization (FAO), andCABI
Journal of Agricultural Extension

Vol. 20 (1) June, 2016

ISSN(e): 24086851; ISSN(Print); 1119944X

http://journal.aesonnigeria.org

http://www.ajol.info/index.php/jae

Email: editorinchief@aesonnigeria.org

Omonona, B., Oni, O., and Uwagboe, O. (2005) "Adoption of improved Cassava varieties and its impact on Rural Farming Households in Edo State, Nigeria". Journal of Agriculture and Food Information 7(1): pp40-45

Onyenweaku, C.E. and Nwaru, J.C. (2005). Application of a stochastic frontier production function to the measurement of technical efficiency in food crop production in Imo State, Nigeria. The Nigerian Agricultural Journal Vol. 36 (2005) 1-12.

Ouma, J., Murithi,F., Mwangi, W., Verkuijl, H., Gethi M, De Groote, H. (2002) Adoption of Maize Seed and Fertilizer Technologies in Embu District, Kenya. CIMMYT (International Maize and Wheat Improvement Center), Mexico, D.F.

Rogers, E.M. and Shoemaker, F. (1971). Communication of Innovations: A Crosscultural Approach. New York. The Free Press pp. $53-70$.

Simtowe F. (2011).Determinants of Agricultural Technology adoption: the Case of Improved Pigeon pea Varieties in Tanzania

Simtowe, F. \& Zeller, M. (2006). The Impact of Access to Credit on the Adoption of hybrid maize in Malawi: An Empirical test of an Agricultural Household Model under credit market failure. MPRA Paper No. 45

Sub-committee for study of diffusion of Farm Practices (1961). The five stage adoption process. Central Regional Extension Publication. No.13 